\title{
Outbreak
}

\section{West Nile Virus outbreak in Sardinia, Italy, in 2011}

\author{
Nicoletta Spissu' ${ }^{1}$, Giovanni Panichi ${ }^{2}$, Antonio Montisci ${ }^{3}$, Filippo Fiore ${ }^{1}$ \\ ${ }^{1}$ Department of Veterinary Medicine, Section of Pathology and Veterinary Clinic, University of Sassari, Sassari, Italy \\ ${ }^{2}$ Private Veterinarian, Oristano, Italy \\ ${ }^{3}$ Azienda Sanitaria Locale -Local Health Agency $n^{\circ} 5$, Animal Health services (area A) Oristano, Italy
}

\begin{abstract}
West Nile Virus (WNV) is an enveloped, positive-sense RNA virus belonging to the genus Flavivirus, antigenically related to the Japanese encephalitis complex in the family Flaviviridae. The principal vectors are mosquitoes, in particular Culex spp, and virus amplification seems to occur in susceptible birds that are the principal vertebrate reservoir hosts, whereas humans, horses and other vertebrates are considered incidental or dead-end hosts. The first Italian equine outbreak was reported in late summer of 1998 in Tuscany, in the area surrounding the Fucecchio marshes, where 14 clinical cases of WND in housed equines were recorded. In 2011 WNV appeared for the first time in Sardinia, representing the first clinical cases in equines in Italy in 2011. The outbreak occurred both in humans and in equines. The serological survey performed on 253 equines living in the province of Oristano detected a total of 87 IgG-positive subjects. Among them, 46 horses showed neurological signs such as ataxia, paresis, paralysis, hyperesthesia, muscle fasciculations, seizures, or fever. Nine of them died or were euthanized. In forthcoming years, surveillance of wild birds and insects will be used to forecast the extension and spread of WNV. The information gathered will be used to direct or optimise strategies intended to prevent virus transmission.
\end{abstract}

Key words: West Nile Virus; Outbreak; Horses; Sardinia; Italy

J Infect Dev Ctries 2013; 7(1):006-009.

(Received 11 January 2013 - Accepted 12 January 2013)

Copyright (C) 2013 Spissu et al. This is an open-access article distributed under the Creative Commons Attribution License, which permits unrestricted use, distribution, and reproduction in any medium, provided the original work is properly cited.

West Nile Virus (WNV) is an enveloped, positivesense RNA virus belonging to the genus Flavivirus, antigenically related to the Japanese encephalitis complex in the family Flaviviridae [1]. Genomic analysis has revealed two genetic lineages of WNV: lineage 1 viruses, circulating in the United States, Europe, the Middle East, Africa, India, and Australia, and lineage 2 viruses, isolated from sub-Saharan Africa and Madagascar [2]. The principal vectors are mosquitoes, in particular Culex spp $[3,4]$ and virus amplification seems to occur in susceptible birds that are the principal vertebrate reservoir hosts [5], whereas humans, horses and other vertebrates are considered incidental or dead-end hosts [6]. Virus transmission occurs especially in coastal plains, wetlands, and semiarid areas with virus activity peaking during hot or rainfall seasons, depending on the geographic area, caused by higher mosquito density and $\backslash$ or increased vector capacity during this season. Bird migration seems to be the major mechanism of WNV dissemination and circulation in Europe [7]. The infection in humans mainly occurs asymptomatically or with mild infection classified as West Nile Fever
(WNF) [8,9]. A very low percentage of patients develop neuroinvasive disease, characterized by meningitis (WNM) or encephalitis (WNE) [10], and the fatality rates for these forms vary from $3 \%$ to $15 \%$ [11]. In horses, the infection is characterized by a short incubation period ( 3 to 15 days, as in humans), and the main symptoms are fever, lacrimation, asthenia, ataxia, weakness, fasciculation, palpebral paralysis, paraparesis, tetraplegia, bruxism, blindness, and death. The morbidity and the severity of the symptoms depend on several factors, including the immune status of the patient and the WNV strain involved. As clinical symptoms do not differentiate WNF from other viral fevers, the etiological diagnosis could be provided by virus isolation and $\backslash$ or serology [12]. Virus can be isolated from blood from the late incubation period to five days after the onset of illness, considering that viremia is relatively low and drops from the second to the third day of illness. The diagnosis in the neuroinvasive disease is made by detecting anti-WNV $\operatorname{IgM}$ antibodies in blood and cerebrospinal fluid. In the majority of cases the infection is sporadic, as a consequence of virus 
introduction through migratory birds from Africa, where WNV extensively circulates $[13,14]$. In fact, in the past years, outbreaks of WNV have been recorded in Northern Africa, specifically in Algeria [15] Morocco [16], Tunisia [17] and again in Morocco in 2003 [18], as well as in several European and Mediterranean countries [19,20].

The first Italian equine outbreak was reported in late summer of 1998 in Tuscany, in the area surrounding the Fucecchio marshes [21], where 14 clinical cases of WND in housed equines were recorded. Subsequent serologic studies revealed that $40 \%$ of horses in the region had WNV neutralizing antibodies. Since 2001, a national veterinary surveillance system based on periodic testing of sentinel chickens and horses has identified sporadic seroconversions [22] without further occurrence of actual WNV disease until 2008 [23]. In August 2008, WND appeared again in Italy in areas surrounding the Po River delta. Like the 1998 strain, the 2008 infection did not cause significant death rates in birds, but it was able to cause clinical symptoms in both equines (32 clinical cases and 5 deaths) and humans (9 clinical cases, 4 with neurological signs). An overall number of 251 outbreaks distributed in three regions (Emilia Romagna, Veneto, and Lombardia) were confirmed. Subsequently, active and passive human surveillance was started in both regions [24]. In July 2009, WNV infection occurred again in the Po River delta area, and spread from there to other regions. A total of 137 equine outbreaks with 122 cases were confirmed in the following regions: Emilia Romagna, Friuli Venezia Giulia, Lazio, Lombardia, Toscana, and Veneto. The surveillance program enabled the identification of 18 human cases of WND. A high degree of homology (98.8\%) was observed among the viruses isolated in Italy in 1998, in 2008, and in 2009. These viruses were quite similar to those West Nile viruses that circulated for about ten years in the Mediterranean basin and in some African regions. These viruses are all part of lineage 1. In 2010 further outbreaks were recorded in the same regions and in new regions. In total, 67 equine outbreaks with 128 cases distributed in Sicilia, Veneto, Molise, and Emilia Romagna were confirmed. The surveillance plan enabled the identification of 6 human cases of WND $[25,26,27]$.

In 2011 WNV appeared for the first time in Sardinia, representing the first clinical cases in equines in Italy in 2011. The outbreak occurred both in humans and in equines. Four human cases were identified, three in the province of Oristano and one in the province of Olbia-Tempio. Table 1 shows the data
Table 1. Number of confirmed WND cases in humans in Sardinia

\begin{tabular}{|l|c|c|c|c|}
\hline Province & $\begin{array}{c}\text { Total } \\
\text { cases }\end{array}$ & Age & Sex & Deceased \\
\hline Oristano & 3 & 34 & $\mathrm{M}$ & 1 \\
\hline & & 75 & $\mathrm{M}$ & 1 \\
\hline & & 84 & $\mathrm{M}$ & 0 \\
\hline $\begin{array}{l}\text { Olbia- } \\
\text { Tempio }\end{array}$ & 1 & 71 & $\mathrm{M}$ & 0 \\
\hline Total & $\mathbf{4}$ & & & $\mathbf{2}$ \\
\hline
\end{tabular}

for the human outbreak as recorded by the Ministry of Health, Department of Prevention and Communication, Directorate General of Preventive Health Care, Infectious Diseases and International Prophylaxis.

The serological survey performed on 253 equines living in the province of Oristano detected a total of 87 IgG-positive subjects, corresponding to a seroprevalence of $34.39 \%$. Among them, 46 horses showed neurological signs such as ataxia, paresis, paralysis, hyperesthesia, muscle fasciculations, seizures, or fever. Nine of them died or were euthanized. The outbreaks that occurred in the provinces of Nuoro (one case), Medio Campidano (two cases), and Cagliari (one case), outside the risk area, were characterised by clinical signs. Cases confirmed in Sardinia by the Centro di Referenza Nazionale per lo Studio delle Malattie Esotiche (CESME) (National Reference Centre for Exotic Diseases) up to 8 November 2011 are reported in Table 2 [28].

As prescribed by the Italian government, in addition to monitoring the horse population, the surveillance plan for the risk areas was based on the mortality of wild birds, the monitoring of captive sentinel chickens and sedentary sinanthropic birds, and on entomological surveillance.

Up to 16 December 2011, five subjects (one Little Owl (Athene noctua), two Common Buzzards (Buteo buteo), and one Wild Duck (Anas platyrhynchos)) tested positive by PCR for WNV in the province of Oristano, which is situated in the risk area, during the surveillance on wild bird mortality. Monitoring of sedentary sinanthropic birds and captive sentinel chickens identified the following PCR positivities: three in Eurasian Jays (Garrulus Glandarius), three in Carrion Crows (Corvus corone cornix), and four in sentinel chickens. 
Table 2. Number of WND confirmed cases in equines in Sardinia

\begin{tabular}{|c|c|c|c|c|c|}
\hline & \multicolumn{4}{|l|}{ Provinces } & \multirow[b]{2}{*}{ Total } \\
\hline & Oristano & Cagliari & Medio Campidano & Nuoro & \\
\hline Number of outbreaks & 31 & 1 & 2 & 1 & 35 \\
\hline $\begin{array}{l}\text { Number of outbreaks with } \\
\text { clinical signs }\end{array}$ & 29 & 1 & 2 & 1 & 33 \\
\hline Subjects tested & 253 & 31 & 10 & 2 & 296 \\
\hline Total cases & 87 & 1 & 2 & 1 & 91 \\
\hline Horses with clinical signs & 46 & 1 & 2 & 1 & 50 \\
\hline Died/euthanized & 9 & & 1 & 2 & 12 \\
\hline Prevalence of cases & $34.39 \%$ & & $3.23 \%$ & $20.00 \%$ & $50.00 \%$ \\
\hline Prevalence of clinical cases & $18.18 \%$ & & $3.23 \%$ & $20.00 \%$ & $50.00 \%$ \\
\hline Mortality & $19.57 \%$ & & $100.00 \%$ & $100.00 \%$ & $0.00 \%$ \\
\hline
\end{tabular}

In the summer of 2012, eight confirmed cases in equines were recorded for the first time in northern Sardinia, in the provinces of Olbia-Tempio and Sassari, as a result of serological screening of horses living in those areas. Additionally, organs from six Carrion Crows (Corvus corone cornix) tested positive for WNV by PCR, indicating that the virus was still circulating in the island [29].

The quick and intensive spread of WNV in the past two years suggests that the whole of Sardinia may be affected in the future. The reoccurrence of WNV in continuous years, in the same places in both humans and equines, is likely to be linked to the endemisation of the infection in the territory rather than to a new introduction of the virus. This situation may introduce new scenarios of risks, especially if the virus will be capable of spreading across wide territories. In forthcoming years, surveillance of wild birds and insects will be used to forecast the extension and spread of WNV. The information gathered will be used to direct or optimise strategies intended to prevent virus transmission, such as monitoring and controlling vectors, providing information campaigns to improve personal protection, and screening blood, tissues, and organs for transplant.

\section{References}

1. Karabatsos N (1985) International catalogue of arboviruses, including certain other viruses of vertebrates. 3rd ed. San Antonio: American Society of Tropical Medicine \& Hygiene.

2. Lanciotti RS, Ebel GD, Deubel V, Kerst AJ, Murri S, Meyer R, Bowen M, McKinney N, Morrill WE, Crabtree MB, Kramer LD, Roehring JT (2002) Complete genome sequences and phylogenetic analysis of West Nile Virus strains isolated from the Unites States, Europe, and the Middle East. Virology 298: 96-105. http://dx.doi.org/10.1006/viro.2002.1449; PMid:12093177.
3. Hayes CG (2001) West Nile virus: Uganda, 1937, to New York City, 1999. Annals of the New York Academy of Science 951: 25-37. http://dx.doi.org/10.1111/j.17496632.2001.tb02682.x; PMid:11797781.

4. Petersen LR, Roehrig JT (2001) West Nile Virus: a reemerging global pathogen. Emerging Infectious Diseases 7: 611-614; PMid:11585520. PMCid:2631751.

5. Granwehr BP, Lillibridge KM, Higgs S, Mason WP, Aronson JM, Campbell GA, Barrett ADT (2004) West Nile virus: where are we now? Lancet Infectious Diseases 4: 547-556. http://dx.doi.org/10.1016/S1473-3099(04)01128-4.

6. Komar N (2000) West Nile viral encephalitis. Rev Sci Tech 19: $166-176$

7. Hayes CG (1989) West Nile Fever in the Arboviruses: Epidemiology and Ecology, vol. V, Monath TP ed CRC press, Boca Raton FL, 59.

8. Mostashari F, Bunning ML, Kitsutani PT, Singer DA, Nash D, Cooper MJ, Katz N, Liljebjelke KA, Biggerstaff BJ, Fine AD, Layton MC, Mullin SM, Johnson AJ, Martin DA, Hayes EB, Campbell GL (2001) Epidemic West Nile encephalitis, New York, 1999: results of a household-based seroepidemiological survey. Lancet 358: 261-264. http://dx.doi.org/10.1016/S0140-6736(01)05480-0.

9. Brown JA, Factor DL, Tkachenko N, Templeton SM, Crall ND, Pape WJ, Bauer MJ, Ambruso DR, Dickey WC, Marfin AA (2007) West Nile viremic blood donors and risk factors for subsequent West Nile fever. Vector-Borne and Zoonotic Diseases 7: 479-488. http://dx.doi.org/10.1089/vbz.2006.0611. PMid:17979539.

10. Craven RB, Roehrig JT (2001) West Nile Virus. Journal of the American Medical Association 344: 1858-1859. Centers for Diseases Control and Prevention-CDC, USA. Available at http://www.cdc.gov. Last accessed 21.11.2012.

11. Kedarnath N, Prasad SR, Dandawate CN, Koshy AA, George S, Gosh SN (1984) Isolation of Japanese encephalitis and West Nile Viruses from peripheral blood of encephalitis patients, Indian J Med Res 79: 1-7.

12. Cabre O, Durand JP, Prange A, Gomez J, Maurizi L, Tolou H, Davoust B (2005) West Nile virus infection:serological investigation among horses in France and in Africa. Med Trop (Mars) 65: 439-443.

13. Chevalier V, Lancelot R, Diaite A, Mondet B, Sall B, De Lamballerie X (2006) Serological assessment of West Nile fever virus activity in the pastoral system of Ferlo, Senegal. 
Ann NY Acad Sci 1081: 216-225. http://dx.doi.org/10.1196/annals.1373.026; PMid:17135514.

14. Murgue B, Murri S, Triki H, Deubel V, Zeller HG (2001) West Nile in the Mediterranean basin: 1950-2000. Ann NY Acad Sci 951: 117-26. http://dx.doi.org/10.1111/j.17496632.2001.tb02690.x; PMid:11797769.

15. Tber AA (1996) West Nile fever in horses in Morocco. Bull OIE 108: 867-869.

16. Triki H, Murri S, Le Guenno B, Bahri O, Hili K, Sidhom M, Dellagi K (2001) West Nile viral meningoencephalitis in Tunisia. Med Trop (Mars) 61: 487-490.

17. Schuffenecker I, Peyrefitte CN, el Harrak M, Murri S, Leblond A, Zeller HG (2005) West Nile virus in Morocco, 2003. Emerg Infect Dis 11: 306-309. http://dx.doi.org/10.3201/eid1102.040817; PMid:15752452 PMCid:3320441.

18. Autorino GL, Battisti A, Deubel V, Ferrari G, Forletta R, Giovannini A, Lelli L, Murri S, Scicluna MT (2002) West Nile virus Epidemic in horses, Tuscany Region, Italy. Emerg Infect Dis 8: 1372-1378. http://dx.doi.org/10.3201/eid0812.020234; PMid:12498650 PMCid:2738505.

19. Calistri P, Giovannini A, Hubalek Z, Ionescu A, Monaco F, Savini G, Lelli R (2010) Epidemiology of West Nile in Europe and in the Mediterranean Basin. The Open Virology Journal 4: 29-37. PMid:20517490 PMCid:2878979.

20. General Directorate for Prevention. Surveillance of West Nile virus infection in Italy. Circular No. 400.3/3.2/ 4234. Available from: www.ministerosalute.it/imgs/C_17 normativa_355_allegato. [In Italian], last accessed 25.11.2012.

21. Rizzoli A, Rosà R, Rosso F, Buckley A, Gould E (2007) West Nile Virus Circulation Detected in Northern Italy in Sentinel chickens. Vector-Borne and Zoonotic Diseases 7: 411-417. http://dx.doi.org/10.1089/vbz.2006.0626; PMid:17767411.

22. Savini G, Monaco F, Calistri P, Lelli R (2008) Phylogenetic analysis of West Nile virus isolated in Italy in 2008. Euro Surveill 13: pii=19048. Available at: http://www.eurosurveillance.org/ViewArticle.aspx?ArticleId= 19048. Last accessed 25.11.2012.
23. Macini P, Squintani G, Finarelli AC, Angelini P, Martini E, Tamba M, Dottori M, Bellini R, Santi A, Loli Piccolomini L, Po C (2008) Detection of West Nile virus infection in horses, Italy, September 2008. Euro Surveill 13: pii=18990, Available at: http://www.eurosurveillance.org/ViewArticle.aspx?ArticleId= 18990. Last accessed 25.11.2012.

24. Filipponi G, Lelli R, Savini G, Giovannini A, Guberti V, Santucci U, Romi R, Toma L, Goffredo M, Caporale V (2005) West Nile Virus surveillance in Italy: results of three years activities. 2005 National Conference on West Nile Virus in the United States, San Jose, California, February, 89.

25. Monaco F, Lelli R, Teodori L, Pinoni C, Di Gennaro A, Polci A, Calistri P, Savini G (2010) Re-emergence of West Nile Virus in Italy. Zoonoses and Public Health 57: 476-486; doi: 10.1111/j.863-2378.009.01245.x. Last accessed 25.11.2012.

26. Calistri P, Giovannini A, Savini G, Monaco F, Bonfanti L, Ceolin C, Terregino C, Tamba M, Cordioli P, Lelli R (2009) West Nile Virus Transmission in 2008 in North-Eastern Italy.. Zoonoses and Public Health doi: 10.1111/j.18632378.2009.01303.x. Last accessed 25.11.2012; http://dx.doi.org/10.1111/j.1863-2378.2009.01303.x.

27. West Nile Disease in Italia nel 2011, http://sorveglianza.izs.it/emergenze/west_nile/pdf/bollettinogi onaliero/2011. Last accessed 15.12.2012.

28. West Nile Disease in Italia nel 2012, http://sorveglianza.izs.it/emergenze/west_nile/pdf/bollettinogi onaliero/bollettinoWND2012.pdf. Last accessed 15.12.2012.

\section{Corresponding author}

Dr. Nicoletta Spissu

Department of Veterinary Medicine

Via Vienna n.2, 07100 Sassari

Italy

Telephone: +39079229481

Fax: +39079229419

Email: nspissu@uniss.it

Conflict of interests: No conflict of interests is declared. 